\title{
Despair of repair
}

\section{Stangel, H-P Hartung}

\section{Intravenous immunoglobulins in multiple sclerosis}

O riginally, intravenous immunoglobulins (IVIg) were designed to provide replacement therapy for patients with hypogammaglobulinaemia. Fortuitously, Imbach et al discovered in the early 1980s that these preparations were beneficial in idiopathic thrombocytopenic purpura. ${ }^{1}$ Since then, IVIg has been tried, at least experimentally, in almost every disease of a presumed autoimmune nature, ${ }^{23}$ and several uncontrolled studies evaluating potential therapeutic benefits of IVIg in multiple sclerosis were published, ${ }^{4-6}$ but it was not until 1997 that the results of controlled trials became available. ${ }^{7} \mathrm{Be}$ sides its iridescent immunomodulatory actions, work in experimental animal models suggested that IVIg could have the potential to remyelinate demyelinated lesions. In the past year several studies, both experimental and clinical, have shed some light on the capacity and mechanism of IVIg to support remyelination.

\section{Controlled studies of IVIg in multiple sclerosis}

Three double blind, randomised, and placebo controlled trials of IVIg in multiple sclerosis have been performed, all in patients with a relapsing-remitting course. $^{7-9}$ The design and main results are summarised in table 1 . There was agreement between the studies that IVIg can reduce the relapse rate. In two of the studies a favourable impact of IVIg on disability assessed by the Kurtzke expanded disability status scale (EDSS) was noted..$^{7}$ Finally, in the two smaller trials that included MRI outcome criteria the number of new and total gadolinium enhancing lesions in the brain was reduced by IVIg, but there was no change in the total number of $\mathrm{T} 2$ weighted lesions. ${ }^{89}$ Although each of the trials was positive for its main outcome parameter, assessment and interpretation of the results pose difficulties. Only one of these studies ${ }^{7}$ included a sufficient number of patients but concern has been expressed about the blinding in this trial as there was overall no decrease in relapse rate in the patients treated with placebo, as would be expected. Furthermore, unfortunately, drug efficacy was not evaluated by MRI, a commonly accepted surrogate marker of disease activity and burden. All three studies used very different treatment protocols with a 10-fold difference in dosage of IVIg administered and hence cannot be directly compared. The high frequency of serious adverse events recorded in one of the studies may be due to the rapid infusion of large doses. ${ }^{8}$ Nevertheless, collectively, results from these trials provided the basis for a consensus statement to consider IVIg as second or third line immunomodulatory treatment in multiple sclerosis. ${ }^{10}$

\section{Why should IVIg remyelinate multiple sclerosis lesions?}

In the past decade, experiments, mainly in the inflammatory demyelinating animal model of Theiler's murine encephalomyelitis virus (TMEV), have demonstrated that immunoglobulins can support remyelination. ${ }^{11}{ }^{12}$ Initially, polyclonal immunoglobulins against spinal cord homogenate were used. Subsequently several monoclonal antibodies that promote remyelination were isolated. The shared characteristics of these monoclonal antibodies are an IgM isotype and binding to oligodendrocytes, independent of epitope specificity. ${ }^{13}$ Recently, also two human monoclonal IgM antibodies with remyelinating capacity in the TMEV model were isolated..$^{14}$ Although the affinity for oligodendrocyte antigens may be necessary, it is not sufficient for these antibodies to promote remyelination. In addition to their effects in the inflammatory virus induced model, these antibodies were capable of accelerating the rate of remyelination in a toxic model of chemically induced demyelination. ${ }^{15}$ However, the extent of remyelination at the termination of the study did not seem to be affected and treatment with steroids had an effect similar in magnitude to that of the monoclonal antibody. Thus, it remains elusive whether the monoclonal antibodies induce remyelination directly or whether the effect is achieved indirectly through modulation of the immune system.

\section{Clinical trials to evaluate remyelination induced by IVIg}

The promising results from the TMEV model encouraged investigators to study IVIg in patients with multiple sclerosis with a permanent neurological deficit. In a small open trial of stable demyelinating optic neuritis, visual acuity improved 1 to 2 months after initiation of IVIg treatment, but was not correlated with improvement of colour vision, light discrimination, or visual evoked potentials. ${ }^{16}$ In another small open trial in patients with multiple sclerosis with a stable motor deficit, improvement in isometric muscle testing after IVIg treatment was noted. ${ }^{17}$ This prompted a double blind, placebo controlled trial, the results of which have recently been published. ${ }^{18}$ Sixty seven patients were randomised in a parallel group design to receive either $0.4 \mathrm{~g} / \mathrm{kg}$ IVIg or placebo for 5 days and every 2 weeks thereafter for 3 months. There was no significant change in muscle strength for the targeted neurological deficit. Similarly, there was no significant difference in any of the secondary outcome measures: EDSS, functional independence measure (FIM), nine hole peg test, and box and blocks test. Interpretation of the results was certainly complicated due to most patients having secondary progressive multiple sclerosis. It may have been unrealistic to detect any significant

Table 1 Controlled studies of IVlg in multiple sclerosis

\begin{tabular}{|c|c|c|c|}
\hline & Fazekas et aP & Achiron et $a^{P}$ & Sørensen et al ${ }^{8}$ \\
\hline Design & Parallel & Parallel & Cross over \\
\hline Patients included & 148 & 40 & 26 \\
\hline Primary outcome & EDSS (sig) & $\begin{array}{l}\text { Yearly exacerbation rate (sig), exacerbation } \\
\text { free time (sig), time to first relapse (sig) }\end{array}$ & MRI (Gd+ lesions) (sig) \\
\hline Secondary outcome & $\begin{array}{l}\text { Number of relapses (sig), time between } \\
\text { relypses (sig), time to first relapse (NS), } \\
\text { severity of relapses (NS) }\end{array}$ & $\begin{array}{l}\text { EDSS (trend, NS), severity of relapse (NS), } \\
\text { MRI (T1, T2, spin echo) (NS) }\end{array}$ & $\begin{array}{l}\text { MRI (T2) (NS), relapse free patients (sig), } \\
\text { number of relapses (NS), multimodal evoked } \\
\text { potentials (NS), EDSS (NS), NRS (NS) }\end{array}$ \\
\hline Dosage & $0.15-0.2 \mathrm{~g} / \mathrm{kg}$ monthly for 2 years & $\begin{array}{l}2 \mathrm{~g} / \mathrm{kg} \text { loading, then } 0.4 \mathrm{~g} / \mathrm{kg} \text { every other } \\
\text { month for } 2 \text { years }\end{array}$ & $\begin{array}{l}2 \mathrm{~g} / \mathrm{kg} \text { monthly for } 6 \text { months, then cross } \\
\text { over }\end{array}$ \\
\hline
\end{tabular}

Sig, significant result; NS, not significant. 
Table 2 Controlled trials to study the remyelinating effects of IVIg in multiple sclerosis

\begin{tabular}{|c|c|c|c|}
\hline & Noseworthy et al ${ }^{18}$ & Stangel et a $\left.\right|^{19}$ & Noseworthy et al. ${ }^{20}$ \\
\hline Design & Parallel & Modified cross over & Parallel \\
\hline Patients included & 67 & 10 & 55 \\
\hline Primary outcome & Targeted neurological deficit & Central conduction velocity & Change in log MAR scores \\
\hline Secondary outcome & EDSS, FS, FIM, 9HPT, BBT & $\begin{array}{l}\text { EDSS, SNRS, time to walk } 20 \text { m, manual } \\
\text { muscle testing }\end{array}$ & $\begin{array}{l}\text { EDSS, Al, FS, VER, visual fields, visual } \\
\text { acuity, measures of disease activity }\end{array}$ \\
\hline Dosage/time & $\begin{array}{l}0.4 \mathrm{~g} / \mathrm{kg} \text { for } 5 \text { days, then every } 2 \text { weeks for } \\
3 \text { months (total } 11 \text { infusions), evaluation after } \\
6 \text { months }\end{array}$ & $\begin{array}{l}0.4 \mathrm{~g} / \mathrm{kg} \text { for } 5 \text { days (total } 5 \text { infusions), } \\
\text { evaluation } 6 \text { weeks later }\end{array}$ & $\begin{array}{l}0.4 \mathrm{~g} / \mathrm{kg} \text { for } 5 \text { days, then every } 4 \text { weeks } \\
\text { for } 3 \text { months (total } 8 \text { infusions), evaluation } \\
\text { after } 6 \text { months }\end{array}$ \\
\hline
\end{tabular}

None of the outcome parameters were statistically significant.

EDSS, Expanded disability status scale; FS, functional systems score; FIM, functional independence measure; 9HPT, nine hole peg test; BBT, box and blocks test; SNRS, Scripps neurological rating scale; Al, abulation index; VER, visually evoked responses.

change in this form of the disease over such a short time. However, results for the 19 patients with relapsing-remitting disease were equally negative. Another small placebo controlled trial in stable patients with relapsing-remitting multiple sclerosis investigated the central motor conduction time by transcranial magnetic stimulation as an indirect but objective measure of CNS demyelination. ${ }^{19}$ Ten patients were treated first with placebo and then with IVIg $(0.4 \mathrm{~g} / \mathrm{kg})$ on 5 consecutive days, the two treatments being separated by an interval of 6 weeks. There was no difference in central motor conduction velocities measured before and 6 weeks after each treatment. Clinically, a small improvement after IVIg treatment was recorded by the Scripps neurological rating scale (SNRS) and manual muscle testing, but this difference was not significant when compared with the placebo period. Finally, a placebo controlled trial in optic neuritis associated with multiple sclerosis has recently been completed. ${ }^{20}$ Fifty five patients were randomised to receive either placebo or 0.4 $\mathrm{g} / \mathrm{kg}$ IVIg for 5 days and then monthly for 3 months. There was no difference between treatment groups for the primary outcome parameter, improvement of visual log MAR scores at 6 months. Similarly, none of the secondary outcome parameters (visual acuity, visual fields, visual evoked responses, EDSS, measures of disease activity) showed a significant change. However, exploratory secondary analyses suggested that IVIg treatment was associated with improvement in visual function ( $\log$ MAR visual scores at 6 months, visual fields at 6 and 12 months) in patients who remained clinically stable by contrast with patients who were judged to have evidence of multiple sclerosis disease activity. Taken together, these results (summarised in table 2) are rather disappointing and IVIg may be unable to reverse or improve a longstanding deficit acquired as a consequence of relapse activity..

\section{In vitro studies}

Complementary to the clinical trials, some in vitro studies were conducted to elucidate the mechanisms by which IVIg could promote remyelination. There is no doubt that IVIg can influence the immune system at multiple levels (table 3, reviewed in Mouthon et al, ${ }^{21}$ Stangel et $a l^{22}$ and Dalakas $\left.{ }^{23}\right)$. A direct remyelinating effect of IVIg could be accomplished through an influence on the function of oligodendrocyte precursor cells, the remyelinating cells of the CNS (fig 1). However, addition of IVIg to the cell culture medium of oligodendrocyte precursor cells had no effect on proliferation, differentiation, or migration. ${ }^{24}$ By contrast, IVIg was able to protect oligodendrocyte precursor cells and oligodendrocytes from antibody mediated complement injury. ${ }^{25}$ Survival of a larger number of oligodendrocyte precursor

\begin{tabular}{|c|c|}
\hline $\begin{array}{l}\text { Component of the } \\
\text { immune system }\end{array}$ & Function modulated/mechanism postulated \\
\hline Fc receptor & $\begin{array}{l}\text { Inhibition of Fc receptor-mediated phagocytosis } \\
\text { Accelerated elimination of autoantibodies via Fc receptor neonate (FcRn) } \\
\text { Blockade of antibody dependent macrophage mediated cellular cytotoxicity } \\
\text { crosslinkage }\end{array}$ \\
\hline Complement & $\begin{array}{l}\text { Binding of } \mathrm{Cl}, \mathrm{C} 3 \mathrm{~b} \text {, and } \mathrm{C} 4 \mathrm{~b} \\
\text { Inactivation of } \mathrm{C} 3 \mathrm{~b}_{2}-\mathrm{Ig} \mathrm{G} \text { complexes } \\
\text { Saturation of } \mathrm{CR} 1 \text { and } C R 3 \text { receptors on activated macrophages }\end{array}$ \\
\hline Anti-idiotypic antibodies & Neutralisation of autoantibodies \\
\hline Cytokines & $\begin{array}{l}\text { Modulation of cytokine production (favouring Th1 over Th2) } \\
\text { Trace amounts of IFN- } \gamma \text { and TGF }-\beta \\
\text { Antibodies against IL-1- } \alpha \text {, LL }-6 \text {, IFN- } \alpha, \beta, \gamma \\
\text { Protective effect against TNF- } \alpha \text { mediated damage }\end{array}$ \\
\hline T cells & $\begin{array}{l}\text { Antibodies against T cell receptor, HLA class I } \\
\text { Antibodies against LFA-1 accessory molecule } \\
\text { Antibodies against activating superantigens } \\
\text { Soluble CD4 and HLA I/II molecules } \\
\text { Enhanced suppressor T cell function }\end{array}$ \\
\hline B cells & $\begin{array}{l}\text { Anti-idiotypic antibodies } \\
\text { Anti-CD5 antibodies: inactivation of autoantibody producing CD20 }(B 1) \text { B cell } \\
\text { subset } \\
\text { Inhibition of antibody production }\end{array}$ \\
\hline
\end{tabular}




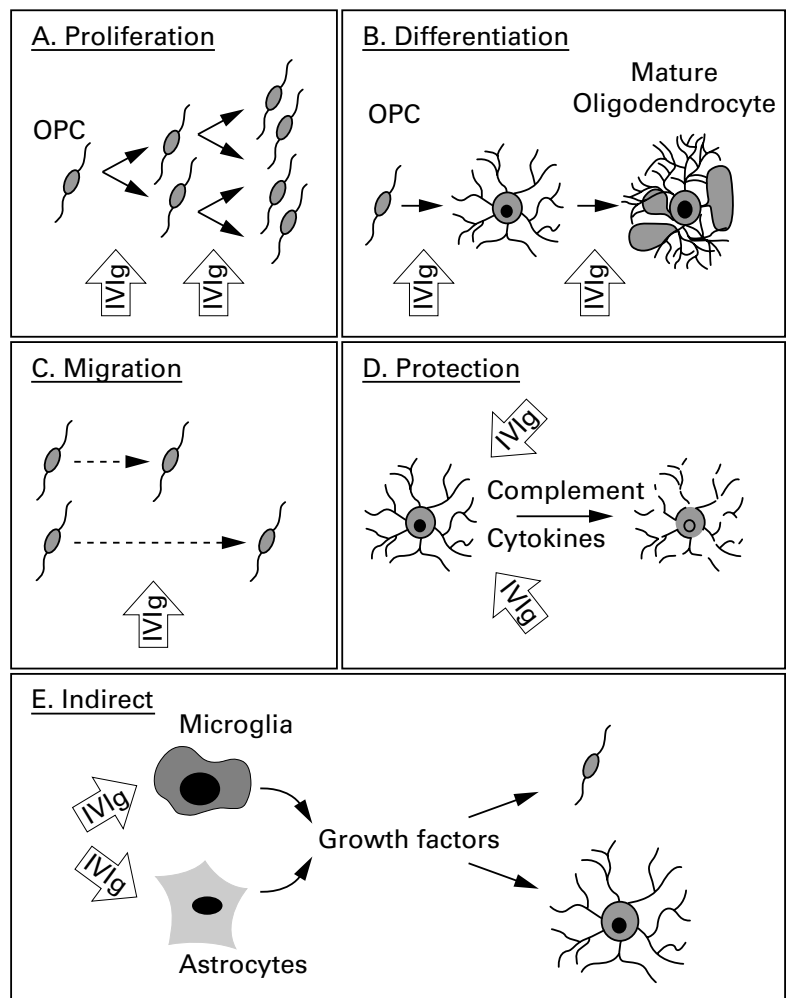

Figure 1 Possible effects of IVlg on oligodendrocytes. (A-C) IVIg can act directly on oligodendrocyte precursor cells (OPCs) by influencing (A) the proliferation of OPCs, (B) differentiation of OPCs to mature oligodendrocytes, or (C) by changing the migratory behaviour of OPCs. (D) A protective effect of IVlg could be achieved through the inhibition of damaging complement deposits or cytokine effects. (E) An indirect effect could be mediated through the modulation of microglia or astrocytes by IVIg that for example, produce growth factors which in turn affect oligodendrocytes or OPCs.

cells after an immune attack would provide more cells to be recruited into demyelinated focal lesions to allow for subsequent remyelination and could thus promote the repair mechanisms. In addition, microglial functions such as phagocytosis, nitric oxide production, and TNF- $\alpha$ secretion can be modulated by IVIg treatment in vitro, ${ }^{26}{ }^{27}$ indicating that the injurious immune reaction in the CNS may be beneficially influenced by IVIg. These results are in line with the data obtained in the TMEV animal model, and support the hypothesis that myelin repair is induced by an indirect immune mechanism. ${ }^{13}$ A scenario could be envisaged in which IVIg acts at several levels, protecting oligodendrocyte precursor cells and oligodendrocytes against a complement driven immune attack, and deviating the immune response to create an environment permissive for remyelination to occur.

\section{CONCLUSIONS}

Promoting CNS remyelination as a repair mechanism is an important goal for the treatment of multiple sclerosis. The administration of immunoglobulins has been a promising approach in animal studies, but the clinical trials in multiple sclerosis recently published were rather disappointing.
Based on experimental data some issues need to be addressed before embarking on future trials. It seems likely that the enhancement of remyelination demonstrated in experimental demyelination is achieved by immunomodulation rather than an immediate effect on oligodendroglial cells. Thus, treatment should be administered at a time when the inflammatory process is still ongoing. So far, all trials that investigated the remyelinating potential of IVIg have been performed in patients with stable deficits at a time when there is probably only little inflammation. The ability of IVIg to modulate inflammatory cells such as microglia in vitro would support this hypothesis. It seems likely that there is only a small yet unknown time window that allows intervention with the remyelinating process. Assuming that IVIg indeed protect oligodendroglial cells from the immune attack in vivo, treatment would need to be started even before a relapse, implying its continuous administration. Thus a possible explanation for the failure to demonstrate an effect of IVIg on myelin repair in multiple sclerosis could be that the treatment regimens adopted so far have not included the ideal time point for remyelination. This includes the question whether sufficient amounts of IVIg can cross the blood-brain barrier in stable disease or if IVIg should be administered during a relapse when the barrier is disrupted. It is, however, difficult to reconcile this hypothesis with the results of the recent optic neuritis trial in which on post hoc analysis, patients without clinical disease activity seemed to receive some benefit. Obviously, another crucial question remains unanswered. Were the right immunoglobulins used? In the TMEV model it was clearly demonstrated that the best results were achieved with IgM, whereas all multiple sclerosis studies have utilised IgG. It is also conceivable that the use of monospecific antibodies rather than pooled immunoglobulin fractions is preferable once epitopes on oligodendrocyte precursor cells relevant to the remyelinative process or factors interfering with it are identified. Further principal concerns remain. Why has IVIg failed to promote remyelination in the clinical trials: Could the gliosis, a consistent pathological feature of chronic multiple sclerosis plaques, prevent any remyelination to occur? Is remyelination sufficient to improve neurological deficits when there is axonal loss, which is a feature already in early lesions ? $^{28}$

Despite the disappointing results from the recent trials of IVIg in multiple sclerosis as a reparative treatment strategy, research into potential repair promoting actions of IVIg should be continued to overcome the shortcomings commented on above. Clearly, the ease of administration would favour such treatment over more complex approaches involving targeted delivery of neurotropic factors or the transplantation of myelinating cells. This includes the favourable side effect profile of IVIg..$^{29}$ Despite recent concerns that blood products may carry the risk of transmission of prion diseases, to date there is no documented instance for IVIg. In general, IVIg is considered a safe medical agent. ${ }^{30}$

None the less, right now the future role of IVIg in the management of multiple sclerosis remains elusive.

\section{Addendum}

While this paper was being processed, the results of a large trial of IVIg in secondary progressive MS (SPMS), the ESIMS trial, were presented (European Charcot Foundation, Venice, 18-20 October 2001). Unfortunately all outcome parameters were negative, suggesting that there is currently no indication for IVIg in SPMS.

J Neurol Neurosurg Psychiatry 2002;72:1-4

\section{Authors' affiliations}

M Stangel, Department of Neurology, Universitätsklinikum Benjamin Franklin, FU Berlin, Berlin, Germany 
H-P Hartung, Department of Neurology, Heinrich-Heine-Universität, Moorenstrasse 5 , D-40225 Düsseldorf, Germany

Correspondence to: Professor H-P Hartung; hans-peter.hartung@mail.uni-duesseldorf.de

\section{REFERENCES}

1 Imbach P, Barandun S, d'Apuzzo V, et al. High-dose intravenous gammaglobulin for idiopathic thrombocytopenic purpura in childhood. Lancet 1981;i:1228-31.

2 Ratko TA, Burnett DA, Foulke GE, et al. Recommendations for off-label use of intravenously administered immunoglobulin preparations. JAMA 1995;273:1865-70.

3 Otten A, Vermeulen M, Bossuyt PMM.

Intravenous immunoglobulin treatment in neurological diseases. J Neurol Neurosurg Psychiatry 1995;59:359-61.

4 Rothfelder U, Neu I, Pelka R. Therapie der Multiplen Sklerose mit Immunglobulin G. Münch Med Wschr 1982;124:48-54.

5 Schuller E, Govaerts A. First results of immunotherapy with immunoglobulin $G$ in multiple sclerosis patients. Eur Neuro 1983;22:205-12.

6 Soukop W, Tschabitscher $H$. Gammaglobulintherapie be Multipler Sklerose (MS). Wien Med Wochenschr 1986; 136:477-80

7 Fazekas F, Deisenhammer F, Strasser-Fuchs $\mathrm{S}$, et al. Randomised placebo-controlled tria of monthly intravenous immunoglobulin therapy in relapsing-remitting multiple sclerosis. Lancet 1997;349:589-93

8 Sorensen PS, Wanscher B, Jensen CV, et al. Intravenous immunoglobulin $G$ reduces MRI activity in relapsing multiple sclerosis. Neurology 1998;50:1273-81

9 Achiron A, Gabbay U, Gilad R, et al. Intravenous immunoglobulin treatment in multiple sclerosis. Effect on relapses. Neurology 1998;50:398-402.

10 Rieckmann P, Toyka KV. Escalating immunotherapy of multiple sclerosis.
Austrian-German-Swiss Multiple Sclerosis Therapy Consensus Group. Eur Neurol 1999;42:121-7.

11 Rodriguez $\mathbf{M}$, Lennon VA. Immunoglobulins promote remyelination in the central nervous system. Ann Neurol 1990;27:12-17.

12 McGavern D, Asakura K, Rodriguez M. Do antibodies stimulate myelin repair in multiple sclerosis? Neuroscientist 1999:5: 19-28.

13 Asakura K, Miller DJ, Pease LR, et al. Targeting of lgMk antibodies to oligodendrocytes promotes CNS remyelination. J Neurosci 1998;18:7700-8

14 Warrington AE, Asakura K, Bieber AJ, et al. Human monoclonal antibodies reactive to oligodendrocytes promote remyelination in a model of multiple sclerosis. Proc Natl Acad Sci 2000;97:6820-5

15 Pavelko KD, van Engelen BGM, Rodriguez $M$. Acceleration in the rate of CNS remyelination in lysolecithin-induced demyelination. J Neurosci 1998;18:2498505.

16 van Engelen BGM, Hommes OR, Pinckers A, et al. Improved vision after intravenous immunoglobulin in stable demyelinating optic neuritis. Ann Neurol 1992;32:834-5.

17 Noseworthy JH, Rodriguez M, An K-N, et al. IVIg treatment in multiple sclerosis: pilot study results and design of a placebo-controlled, double-blind clinical trial. Ann Neurol 1994;36:325

18 Noseworthy JH, O'Brien PC, Weinshenker $B G$, et al. IV immunoglobulin does not reverse established weakness in MS. A double-blind placebo-controlled trial. Neurology 2000;55: $1135-43$.

19 Stangel $M$, Boegner $F$, Klatt $C H$, et al. A placebo-controlled pilot trial to study the remyelinating potential of intravenous immunoglobulins in multiple sclerosis. J Neurol Neurosurg Psychiatry 2000;68:89-92.

20 Noseworthy JH, O'Brien PC, Petterson TM, et al. A randomized trial of intravenous immunoglobulin in inflammatory demyelinating optic neuritis. Neurology (in press).
21 Mouthon L, Kaveri SV, Spalter $\mathrm{SH}$, et al. Mechanisms of action of intravenous immune globulin in immune-mediated diseases. Clin Exp Immunol 1996;104(suppl 1):3-9.

22 Stangel M, Toyka KV, Gold R. Mechanisms of high-dose intravenous immunoglobulins in demyelinating diseases. Arch Neurol 1999;56:661-3.

23 Dalakas M. Mechanism of action of intravenous immunoglobulin and therapeutic considerations in the treatment of autoimmune neurologic diseases. Neurology

1998;51 (suppl):S2-8.

24 Stangel M, Compston A, Scolding NJ. Polyclonal immunoglobulins for intravenous use do not influence the behaviour of cultured oligodendrocytes. J Neuroimmunol 1999;96:228-33.

25 Stangel M, Compston A, Scolding NJ. Oligodendroglia are protected from antibody mediated complement injury by normal immunoglobulins (IVlg). J Neuroimmunol 2000;103:195-201.

26 Stangel $M$, Joly E, Scolding NJ, et al. Normal polyclonal immunoglobulins (IVIg) inhibit microglial phagocytosis in vitro. $J$ Neuroimmunol 2000;106:137-44

27 Stangel $M$, Compston A. Polyclonal immunoglobulins (IVlg) modulate nitric oxide production and microglial functions in vitro via Fc receptors. J Neuroimmunol 2001;112:63-71.

28 Trapp BD, Peterson J, Ransohoff RM, et al. Axonal transection in the lesions of multiple sclerosis. N Engl J Med 1998:338:278-85.

29 Stangel $M$, Hartung H-P, Marx P, et al. Side effects of high dose intravenous immunoglobulins. Clin Neuropharmacol 1997;20:385-93.

30 Nydegger UE, Sturzenegger M. Adverse effects of intravenous immunoglobulin therapy. Drug Safety 1999;21:171-85. Imbach P, Barandun S, d'Apuzzo V, et al. High-dose intravenous gammaglobulin for idiopathic thrombocytopenic purpura in childhood. Lancet 1981;i:1228-31. 